\title{
Investigation of Antibody-Dependent Enhancement (ADE) of SARS coronavirus infection and its role in pathogenesis of SARS
}

\author{
Ming S Yip ${ }^{1 *}$, Chung Y Cheung ${ }^{2}$, Ping H Li ${ }^{1}$, Roberto Bruzzone ${ }^{1}$, JS Malik Peiris ${ }^{1,2}$, Martial Jaume ${ }^{1}$ \\ From Institut Pasteur International Network Annual Scientific Meeting \\ Hong Kong. 22-23 November 2010
}

Antibody-dependent enhancement (ADE) is a mechanism by which viruses, such as dengue, HIV and Ebola, gain entry into some target cells through the use of host antiviral humoral immune responses [1]. Here, we studied the ability of severe acute respiratory syndrome coronavirus (SARS-CoV) [2] to use ADE mechanisms to enhance its infectivity towards cells of the hematopoietic lineage.

We found that heat-inactivated immune serum from rodents vaccinated with recombinant native full-length Spike protein trimers [3] triggered infection of human immune cells (monocytic and B cell lines) by SARS-CoV Spike pseudotyped particle (SARS-CoVpp). The occurrence of antibody-mediated infection of human Raji B cells was further investigated by using live SARS-CoV. Similarly to results obtained with the SARS-CoVpp, only anti-SARS-CoV Spike serum, but not mock immuneserum, induced a massive increase of SARS-CoV viral genes (ORF1b and Nucleocapsid) and viral proteins (Membrane and Nucleocapsid) in Raji B cells. As revealed by immunostaining, only a relatively low, however significant percentage of the Raji cells get infected by antibody-mediated infection and did not allow direct assessment of productive replication by conventional cytopathic assays and TCID50 titration.

Taken together, our data suggested that SARS-CoV is able to enter human immune cells via an antibodymediated pathway and immunological consequences of such infection are under investigation (productive replication, cytokines secretion profile and cell death etc). Our data raise reasonable concerns regarding the use of SARS-CoV vaccine in humans and pave the way to further studies focusing on the role of

\footnotetext{
* Correspondence: simonyms@hkusua.hku.hk

${ }^{1}$ HKU-Pasteur Research Centre, Hong Kong, Hong Kong SAR

Full list of author information is available at the end of the article
}

immune-mediated infection phenomenon during SARS pathogenesis.

\section{Author details}

'HKU-Pasteur Research Centre, Hong Kong, Hong Kong SAR. ${ }^{2}$ Department of Microbiology, The University of Hong Kong, Hong Kong SAR.

Published: 10 January 2011

\section{References}

1. Takada A, Kawaoka Y: Antibody-dependent enhancement of viral infection: molecular mechanisms and in vivo implications. Rev Med Virol 2003, 13:387-398.

2. Du L, He Y, Zhou Y, Liu S, Zheng BJ, Jiang S: The spike protein of SARSCoV-a target for vaccine and therapeutic development. Nat Rev Microbiol 2009, 3:226-236.

3. Kam YW, Kien F, Roberts A, Cheung YC, Lamirande EW, Vogel L, Chu SL, Tse J, Guarner J, Zaki SR, Subbarao K, Peiris M, Nal B, Altmeyer R: Antibodies against trimeric $S$ glycoprotein protect hamsters against SARS-CoV challenge despite their capacity to mediate FcgammaRIIdependent entry into B cells in vitro. Vaccine 2007, 25:729-740.

\section{doi:10.1002/rmv.405}

Cite this article as: Yip et al: Investigation of Antibody-Dependent Enhancement (ADE) of SARS coronavirus infection and its role in pathogenesis of SARS. BMC Proceedings 2011 5(Suppl 1):P80.

Submit your next manuscript to BioMed Central and take full advantage of:

- Convenient online submission

- Thorough peer review

- No space constraints or color figure charges

- Immediate publication on acceptance

- Inclusion in PubMed, CAS, Scopus and Google Scholar

- Research which is freely available for redistribution 